\section{Association between the functional capacity of dependant elderly people and the burden of family caregivers}

\author{
Associação entre a capacidade funcional de idosos \\ dependentes e a sobrecarga do cuidador familiar \\ Asociación entre la capacidad funcional de personas mayores \\ dependientes y la carga para los cuidadores familiares
}

\author{
Ana Cláudia Fuhrmann ${ }^{a}$ \\ Carla Cristiane Becker Kottwitz Bierhals ${ }^{b}$ \\ Naiana Oliveira dos Santos ${ }^{c}$ \\ Lisiane Manganelli Girardi Paskulin ${ }^{d}$
}

\begin{abstract}
The aim of this study was to characterize dependent elderly people and their main family caregivers and the association between functional capacity of the elderly and the burden of caregivers. This cross-sectional study was conducted with 112 elderly people and caregivers connected to a primary care service in Porto Alegre, Brazil. The applied instruments related to care and socioeconomic variables were Physical and Instrumental Activities of Daily Living (PADL and IADL) and the Burden Interview. The Spearman correlation coefficient was also used. Average age of the elderly individuals in this study was 81.41 years, while the average score for PADL was 10.36 and 6.25 for IADL. Of the 112 elderly individuals, $71.4 \%$ had severe dependence. Among caregivers, $75 \%$ were women, $61.6 \%$ were the sons or daughters with an average age of 57.98 and an average burden of 29.53 , which is equivalent to moderate burden. Results revealed a significant correlation between functional capacity of the elderly and caregiver burden. It was verified that the higher the dependence of elderly people, the greater the burden of caregivers.
\end{abstract}

Keywords: Frail elderly. Aging. Caregivers. Geriatric nursing. Primary health care.

\section{RESUMO}

A investigação objetivou caracterizar os idosos dependentes e seus cuidadores familiares principais e verificar a associação entre a capacidade funcional do idoso e a sobrecarga do cuidador. Estudo transversal com 112 idosos/cuidadores vinculados a uma unidade básica de Porto Alegre. Instrumento com variáveis socioeconômicas, relacionadas ao cuidado, escalas de Atividades Físicas e Instrumentais de Vida Diária (AFVDs e AIVDs) e Burden Interview foram aplicados. Utilizou-se teste de Correlação de Spearman. A média de idade dos idosos foi de 81,41 anos, o escore médio para as AFVDs foi 10,36 e 6,25 para AIVDs. Dos 112 idosos, 71,4\% possuíam dependência grave. Dos cuidadores, $75 \%$ eram mulheres, 61,6\%, filhos, com média de idade de 57,98 anos e de sobrecarga de 29,53, equivalente à sobrecarga moderada. Houve correlação significativa entre a capacidade funcional dos idosos e a sobrecarga do cuidador. Verificou-se que, quanto maior a dependência do idoso, maior a sobrecarga do cuidador.

Palavras-chave: Idoso fragilizado. Envelhecimento. Cuidadores. Enfermagem geriátrica. Atenção primária à saúde.

\section{RESUMEN}

La investigación tiene como objetivo caracterizar las personas mayores dependientes y sus cuidadores principales de la familia y comprobar la asociación entre la capacidad funcional de las personas mayores y la carga de los cuidadores. Estudio transversal con 112 ancianos / cuidadores vinculados a una unidad básica de Porto Alegre. Aplicaron instrumentos relacionados a la atención y las variables socioeconómicas, las escalas de Actividades Físicas e Instrumentales de la Vida Diaria (AIVD y PADL) y la Burden Interview. Se utilizó la prueba de correlación de Spearman. La edad promedio de los ancianos fue 81,41 años, la puntuación promedio para PADL fue 10,36 y 6,25 para las AIVDs. De 112 ancianos, 71,4\% tenía dependencia severa. Entre los cuidadores, 75\% era mujeres, 61,6\% niños con una edad promedio de 57,98 años y una carga promedio de 29,53 equivalente a carga moderada. Hubo una correlación significativa entre capacidad funcional de las personas mayores y carga de los cuidadores. Se encontró que, la mayor es la dependencia de los ancianos, la mayor carga del cuidador.

Palabras clave: Anciano frágil. Envejecimiento. Cuidadores. Enfermería geriátrica. Atención primaria de salud.
D0l: http://dx.doi.org/10.1590/1983-

1447.2015.01.49163 a Nurse from the Universidade Federal do Rio Grande
do Sul. Porto Alegre, Rio Grande do Sul (RS), Brazil.
${ }^{b}$ Master's degree student of the Undergraduate
Nursing Programme of the Universidade Federal do
Rio Grande do Sul (PPGENF/UFRGS). Scholarship for
the Coordenação de Aperfeiçoamento de Pessoal do
Ensino Superior (CAPES). Porto Alegre, RS, Brazil.
'Doctoral degree student of the PPGENF/UFRGS.
CAPES Scholarship. Porto Alegre, RS, Brazil.
d Doctoral degree student in Health Sciences. Adjunct
professor of the Undergraduate course and Permanent
professor from the Undergraduate Programme at the
School of Nursing of the Universidade Federal do Rio
Grande do Sul. Porto Alegre, RS, Brazil. 


\section{DINTRODUCTION}

Longevity, when associated to non-communicable diseases, can affect functional capacity (FC) in the elderly, preventing them from independently performing daily activities ${ }^{(1)}$. FC can be defined as "the capacity to maintain the physical and mental abilities required for an independent and autonomous lifestyle $\mathrm{e}^{\prime \prime(2)}$

As impaired FC increases, elderly individuals need the help of other people to perform their activities. These people assume the role of caregivers ${ }^{(3)}$.

Caregivers can be categorized as formal and informal. The formal caregiver is a professional who provides a paid service. An informal caregiver is a member of the family or community who voluntarily provides any type of care to dependent people according to their needs. They can also be considered the main caregivers when they assume full or most of the responsibilities of care giving and conduct most of the activities ${ }^{(1)}$.

Studies that address the caregiver universe show that this function is generally assumed by a member of the family ${ }^{(4-5)}$. These caregivers generally offer full-time care to their elderly family member. The act of caregiving involves positive aspects, such as the feeling of duty accomplished, self-satisfaction and reciprocity, and negative aspects, such as family conflicts, insecurity and burden ${ }^{(3)}$. The Burden Interview (BI), created by Zarit in 1987, measures the subjective burden of caregivers, that is, physical, psychological, emotional, social and financial problems experienced by caregivers as a result of their roles as the providers of care ${ }^{(6)}$.

Brazilian studies have already identified the relationship between FC of the elderly and caregiver burden ${ }^{(3-5,7)}$, but these studies were conducted in other contexts, mostly in the South-east Region, and the subject has not been fully explored in the South Region of Brazil. Considering the diversity of Brazil and the fact that Porto Alegre was the capital city with the largest elderly population, according to the 2010 Census ${ }^{(8)}$, there is a need to expand this topic. It should also be acknowledged that this issue tends to become a public health problem.

Nursing plays an important role in the work of elderly caregivers inasmuch as it assesses vulnerable situations and establishes the correct practices, contributing to the reduction of burden and preventing future complications. This study also extends scientific knowledge on the subject by helping to direct intervention proposals based on the needs of the studied group.

The guiding question created for this study was: What is the relationship between the functional capacity of the elderly and the care burdens of the main family caregiver? The purpose of this study was to characterize dependent elderly people and their main family caregivers in relation to socioeconomic, demographic, health and care-related aspects, and verify the association between FC of elderly people and caregiver burden.

\section{METHODS}

This study is based on a master's dissertation on the validation of a care burden scale for the main family caregivers of dependent elderly people ${ }^{(9)}$.

This is a cross-sectional study with a qualitative approach and secondary data. The original study was conducted at the Santa Cecília Primary Care Unit (UBS) of the Hospital de Clínicas de Porto Alegre/RS (HCPA).

The study base consisted of main family caregivers of elderly people, totalling a sample of 120 elderly people and their respective caregivers. Of these 120 caregivers, eight did not answer the Burden Interview used in this study. Inclusion criteria of the original study were: self-appointed main caregiver of a family member aged 60 or over, who depends on the help of others to perform one or more Activities of Daily Living (ADL), resident in the area covered by the UBS and/or registered at the unit. The caregivers were selected from a Home Care Programme (PAD) list at the unit. Exclusion criteria were: caregiver under the age of 18 , and those who were not contacted after three attempts on different days and shifts. In this study, to verify the association between FC and caregiver burden, considering a significance level of $5 \%(p<0.05)$ and a statistical power of $90 \%$, the sample calculation resulted in 113 subjects, which was similar to the available number $(n=112)$.

Data were collected from September 2011 to June 2012. Interviews were conducted at the homes of the interviewees or at the UBS, according to their preference or availability, in a private room without the presence of other family members or companions. The caregivers were given a questionnaire with socioeconomic, demographic and care-related information based on the Burden Interview. For the elderly participants, information on age and income was collected, followed by the Physical Activities of Daily Living (PADL) and the Instrumental Activities of Daily Living (IADL) scales.

The PADL scale, created by Katz and collaborators, assesses independence when performing functions such as eating, bathing, dressing, and others. The IADL scale, created by Lawton \& Brody, assesses the capacity of elderly people to perform more complex activities, such as using 
the phone, using means of transport, going shopping and others. Each scale consists of seven activities. According to their capacity to perform activities, elderly individuals get a score from zero to 2 points: 2 points for each activity performed without help, 1 point for each activity performed with partial help and zero for each activity that the elderly individual cannot perform. The maximum score is 28 points, and the lower the score, the greater the dependence ${ }^{(10)}$. The PADL and IADL scales were validated for Brazil by Ramos, and Cronbach's coefficient alpha value was 0.88 . The author proposed the classification of elderly people into four categories, according to the level of dependence for AVDs, namely: independent, elderly people that do not need help to perform the 14 AVD; slightly dependent, elderly people who need help to perform from one to three AVD; moderately dependent, elderly people who need help to perform from four to six AVD; and severely dependant, for elderly people who need help to perform seven or more AVD ${ }^{(10)}$.

The Burden Interview contains 22 items that reflect areas of concern of the respondents: health, personal and social life, financial situation, emotional well-being and interpersonal relationships. The scores vary from zero to 4 , in which zero is never, 1 is rarely, 2 is sometimes, 3 is frequently and 4 is always, being that the possible total score for all items can range from zero to 88 points, and the higher the score, the greater the burden of the caregiver. This interview was translated and validated for use in Brazil in a study on the caregivers of people with mental diseases, with Cronbach's coefficient alpha of $0.87^{(11)}$. To verify the level of caregiver burden, the classification according to cut-off scores was used: scores from zero to 20 corresponded to low or no burden, scores from 21 to 40 represented moderate burden, from 41 to 60 for moderate to severe burden, and 61 to 80 for severe burden ${ }^{(3)}$.

Data were analysed by means of average, standard deviation, median and interquartile range for continuous variables and absolute and relative frequency for categorical variables. To verify the association between FC and burden, Spearman's correlation coefficient was used with the Statistical Package for the Social Sciences (SPSS) software version 18.0. Spearman's correlation coefficient varies from -1 to $+1, r=-1$ corresponding to the perfect negative correlation and $r=+1$ corresponding to the perfect negative correlation, passing by value zero (absence of correlation) $)^{(12)}$.

The original study was approved by the HCPA Research Ethics Committee (no 110024). Participants signed an informed consent statement and were identified as Elderly 1 , Elderly 2, Caregiver 1, Caregiver 2, and so forth.

\section{RESULTS}

The sample of this study was 112 subjects.

In terms of the elderly people, average age was 81.41 years ( \pm 9.3$)$. Around $91.1 \%$ had their own income and this income in minimum wages had a median of 1.1 with a variation between 1.0 and 11.5 wages.

In relation to the FC of the elderly participants, the average score was $10.36( \pm 3.4)$ for PADL and 6.25 ( \pm 3.2$)$ for IADL. Table 1 shows the classification of elderly people according to $F C$, revealing that $71.4 \%$ of elderly people had severe dependency and required full or partial help to perform seven or more AVD.

Table 2 shows the socioeconomic, demographic and care-related aspects of the caregivers.

With regard to caregiver burden, the Bl showed an average score of $29.53( \pm 15.1)$, which is equivalent to moderate burden. Table 3 shows the classification of caregivers of elderly people according to burden, and that $46.4 \%$ of caregivers presented a moderate burden.

Table 4 shows that there was a significant correlation between FC of the elderly and caregiver burden. It was observed that the lower the score in the independence scale, the greater the burden, that is, the more dependent the elderly individual, the greater the burden of the caregiver.

\section{DISCUSSION}

In this study, there was a prevalence of older elderly people than in other investigations on caregiver burden and dependent elderly people ${ }^{(3,13-14)}$. In this type of study and in the location where it was conducted, average age is expected to be higher as longevity can be associated to the loss of capacity to perform tasks independently.

With reference to $F C$, the observed average score was lower for IADL than for PADL, which shows greater dependence of elderly people when performing complex activities. In an investigation on elderly people in a Home In-Patient Centre in Rondônia conducted with the Law-

Table 1. Classification of elderly people according to functional capacity. Porto Alegre/RS, Brazil 2012.

\begin{tabular}{lcc}
\multicolumn{1}{c}{ Classification } & n & \% \\
\hline Slightly dependent & 8 & 7.2 \\
Moderately dependent & 24 & 21.4 \\
Severely dependent & 80 & 71.4 \\
\hline Total & 112 & 100.0 \\
\hline
\end{tabular}

Source: ${ }^{(9)}$ 
Table 2. Socioeconomic, demographic and care-related characteristics of caregivers. Porto Alegre/RS, Brazil 2012.

\begin{tabular}{|c|c|}
\hline Variables & $n=112$ \\
\hline Age (years)* & $57.98 \pm 13.57$ \\
\hline \multicolumn{2}{|l|}{ Sex ${ }^{* *}$} \\
\hline Female & $84(75)$ \\
\hline Schooling (years)* & $12.2 \pm 5.24$ \\
\hline \multicolumn{2}{|l|}{ Marital status ${ }^{* *}$} \\
\hline Married & $53(47.3)$ \\
\hline Single & $31(27.7)$ \\
\hline Divorced & $16(14.3)$ \\
\hline Widowed & $12(10.7)$ \\
\hline \multicolumn{2}{|c|}{ Relationship with the elderly person ** } \\
\hline Son/Daughter & $69(61.6)$ \\
\hline Companion & $20(17.9)$ \\
\hline Grandchild & $4(3.6)$ \\
\hline Sibling & $4(3.6)$ \\
\hline Other & $15(13.4)$ \\
\hline \multicolumn{2}{|c|}{ Resides with the elderly person ** } \\
\hline Yes & $73(65)$ \\
\hline \multicolumn{2}{|c|}{ Other people help with the care ** } \\
\hline Yes & $66(58.9)$ \\
\hline \multicolumn{2}{|c|}{$\begin{array}{l}\text { Caregiver has expenses to care for } \\
\text { the elderly person ** }\end{array}$} \\
\hline Yes & $72(60)$ \\
\hline Time of care (years)* & $2.87 \pm 1.18$ \\
\hline Hours of care per week* & $70(1.75-168)$ \\
\hline
\end{tabular}

Source: (9)

${ }^{*}$ continuous variables (average and SD; median and interquartile range). ${ }^{* *}$ categorical variables (\%).

ton's IADL scale, the average score was 12.38 for IADL. In relation to $\mathrm{PADL}$, evaluated with the Katz scale, $42.4 \%$ of the elderly people were fully dependent. The authors emphasize the association between the two instruments, being that the greater the dependence for PADL, the greater the dependence for IADL. This reinforces the importance of using both scales in a complementary manner to assess FC of the elderly ${ }^{(7)}$.

Of the 112 elderly people, 71.4\% were severely dependent. In an investigation conducted in João Pessoa that evaluated the burden of family caregivers of dependent elderly people, almost half (48.1\%) of the elderly people showed dependence to perform all PADL. Evaluating FC
Table 3. Classification of caregivers according to burden. Porto Alegre/RS, Brazil 2012.

\begin{tabular}{lcc}
\multicolumn{1}{c}{ Classification } & n & \% \\
Low or no burden & 37 & 33 \\
Moderate burden & 52 & 46.4 \\
Moderate to severe burden & 19 & 17 \\
Severe burden & 4 & 3.6 \\
\hline Total & 112 & 100.0 \\
\hline
\end{tabular}

Source: ${ }^{(9)}$

Table 4. Correlation coefficients of functional capacity of elderly people and caregiver burden. Porto Alegre/RS, Brazil 2012.

\begin{tabular}{|c|c|c|}
\hline & Burden Interview & $\mathbf{p}$ \\
\hline $\mathrm{PADL}^{*}$ & $-0.394^{* * *}$ & $<0.001$ \\
\hline IADL** & $-0.340^{* * *}$ & $<0.001$ \\
\hline
\end{tabular}

of the elderly is an important health care strategy insofar as it allows the identification of risk factors and monitoring the clinical evolution of health problems, which in turn enables the autonomy and independence of the elderly ${ }^{(15)}$.

In relation to caregiver characteristics, it was observed that $70 \%$ were women, corroborating with other national and international studies on the caregivers of elderly people $e^{(3-5,16-17)}$. This fact reinforces the social role that is culturally attributed to women in terms of house work and tending to the health of family members.

The average age of caregivers was higher than the average ages in other national studies on the caregivers of dependent elderly people $e^{(3,5,14)}$ and in a population study ${ }^{(5)}$, suggesting that people who are approaching old age in this region of Brazil are tending to elderly people, which creates new demands for health services. Older caregivers may have difficulty in providing care to another elderly person, as they must cope with the physical and functional limitations of their own aging process $^{(14)}$.

The high level of education of caregivers in this study was also observed. This fact differs from that of investigations in other national regions on the caregivers of elderly people, where low levels of education were observed ${ }^{(5,7)}$. It should be noted that the subjects of the present study are part of the UBS located in a region with the highest 
levels of education and income of the municipality, according to data of the last Demographic Census ${ }^{(8)}$. It is believed that the socioeconomic factor can influence education levels of the subjects. It is inferred that more years of study help to diminish the burden, as these caregivers acquire a better understanding of guidelines provided by health care professionals, and thus find it easier to provide care to others.

With regard to the caregivers' marital status, $47.3 \%$ were married, which is similar to data from other studies on the caregivers of dependent elderly people ${ }^{(14,18)}$. To be married can increase the burden of caregivers due to the accumulation of activities they must perform, but it can also be positive insofar as they get support to perform activities. ${ }^{(14,18)}$.

In relation to relationship with the elderly individuals, 61.6\% were sons or daughters, which was also found in other studies on dependent elderly people ${ }^{(5,15)}$. This finding can be attributed to the fact that older elderly people cannot tend to their spouses, as they also have incapacities, and must rely on other family members to assume this task. The fact that their children undertook to care for their elderly parents can also be attributed to a cultural and social issue. In a study conducted in the South Region of Brazil, the children of elderly people assumed the commitment of tending to their parents as a natural and expected process, as retribution for care they received as children, and as an act of love and esteem for their parents ${ }^{(19)}$.

Of the interviewees, $65 \%$ resided with the elderly person, which was also found in other studies on the caregivers of dependent elderly people ${ }^{(5,13)}$. For the elderly, this situation can be beneficial, as their demands can be easily met by the caregiver. Withal, it can also increase the burden, considering that the demands and dedication are high and caregivers are exposed to the effects of caregiving on a daily basis ${ }^{(5)}$.

Of the caregivers, approximately 59\% stated they got help from another person when caring for the elderly, which can be a positive factor due to the high demands of taking care of a dependent elderly person, while also allowing caregivers to maintain a social life, enjoy moments of leisure and intimacy. Nurses can help by providing guidelines, answering the queries of caregivers and showing better ways of giving care, which also reduces the burden of caregivers ${ }^{(13)}$.

In contrast, $60 \%$ of caregivers stated they used their own income to cover the costs of providing care to the elderly family member. Use of one's own financial resources to tend to an elderly person reduces the resources avail- able for personal or family expenses, which interferes with the family economy and dynamics. This limitation can generate stress and burden, as providing care starts to be considered a duty ${ }^{(3,7)}$. Furthermore, $91.1 \%$ of the elderly people had an income, but most of the caregivers still used their own income to cover the costs of caregiving. This finding shows that the costs of providing care to a dependent person are high and forces the rest of family to use their own financial resources to meet the needs of the elderly member.

With reference to caregiver burden, an average of $29.53( \pm 15.1)$ was obtained with the $B I$, which is similar to findings of other studies that adopted this instrument (3-5). In relation to level of burden, almost half of the sample presented moderate burden, also similar to other studies ${ }^{(3,14)}$.

Providing care to a dependent elderly person is a complex task that requires time and dedication. Many caregivers provide full-time care and leave their well-being aside to remain at the disposal of the elderly family member. The burden can lead to the appearance or intensification of health-related complications of caregivers, as they oftentimes neglect their own care to maintain the difficult routine of providing care to the elderly (3). The findings listed previously are particularly important in a region where caregivers are also of advanced age. Giving priority to the assessment of caregiver burden, among other aspects, especially in primary care and home care services, and including caregivers in the nursing care plans, is thought to help both the caregivers, by defining specific support interventions, and the elderly who receive this care.

Results showed a statistically significant association between FC of the elderly and caregiver burden, with inversely proportional averages, that is, the lower the independence score of the elderly person, the greater the caregiver burden. This result was also found in other national studies that used the same instruments ${ }^{(7,15)}$ and different scales to assess CF and burden ${ }^{(5,14)}$.

Dependent elderly people need more complex and frequent care, forcing caregivers to plan and organize their lives according to the needs of their elderly family members. Moreover, the dependence of the elderly tends to create the social isolation of caregivers because they must spend most of their time at home, due to the difficulties in moving the elderly from one place to another, due to fear and concerns of the caregivers ${ }^{(13)}$ or because there is no other person with whom to share the task of caregiving.

Individuals who previously led an autonomous and independent life tend to feel the effects of this change. 
They sometimes feel sad and discouraged to go on with their lives. This affects the people around them and they become a burden for caregivers, who struggle to cheer these individuals up. On the other hand, results also showed that the well-being of caregivers has an impact on the care provided to the elderly, that is, the burden of caregivers can reduce the quality of care provided to the elderly.

Caring for a dependent elderly person is a complex task that requires dedication, knowledge and, in some cases, the renouncement of interpersonal relationships. The scales that assess FC are important tools to detect the limitations of elderly people and support nurses in the prevention of incapacities and consequently reduce the burden of care, considering that the FC of the elderly is an important predictor of caregiver burden.

\section{CONCLUSION}

In this study, there was a prevalence of older elderly people with severe dependence. Most caregivers were married women with a high level of education and an average age of 57.98 . Of the caregivers, $61.6 \%$ were sons or daughters, most resided with the elderly family member, had to cover the costs of care, and received the help of other people to care for the elderly member. In addition, $46.4 \%$ of the caregivers presented moderate burden. It was also noted that the higher the dependence of the elderly person, the greater the burden of the caregiver.

Assessing the level of caregiver burden by using the appropriate instruments allows nurses to establish how the task of caring interferes with the quality of life of caregivers, and therefore helps them to create strategies to cope with the situation. Nurses can help reduce the burden by creating caregiver groups and providing guidelines and information on the provision of care.

It is also necessary to implement the existing public policies that target the prevention of health-related complications and promote the health of elderly people, and extend policies for the caregivers of elderly people. In relation to the education of health care professionals, teaching institutions are making some attempts to address issues related to population aging and its implications, but this approach must be intensified by qualifying better prepared professionals to provide support for caregivers and those who interact with elderly people on a daily basis, not only in the field of specialities, but also within the context of primary and home care.

The limitation of this investigation was the use of secondary data in a cross-sectional study, which prevents the analysis of cause and effect between the FC of elderly people and caregiver burden. The conduction of longitudinal studies is therefore suggested to address these issues and support the practices of health care professionals.

\section{口EFERENCES}

1. Guimarães ML, Souza MCMR, Azevedo RS, Paulucci TD. 0 cuidado ao idoso em saúde coletiva: um desafio e um novo cenário de prática. In: Souza MCMR, Horta NC, organizadores. Enfermagem em saúde coletiva: teoria e prática. São Paulo: Guanabara Koogan; 2012.

2. Ministério da Saúde (BR). Portaria № 2.528, de 19 de outubro de 2006. Aprova a Política Nacional de Saúde da Pessoa Idosa. Brasília (DF); 2006 [2014 nov 10]. Available in: http://dtr2001.saude.gov.br/sas/PORTARIAS/Port2006/GM/GM2528.htm

3. Nardi EFR, Sawada NO, Santos JLF. Associação entre a incapacidade funcional do idoso e a sobrecarga do cuidador familiar. Rev Latino-Am Enfermagem. 2013;21(5):1093-113.

4. Stackfleth R, Diniz MA, Fhon JRS, Vendruscolo TRP, Fabrício-Whebe SCC, Marques $S$, et al. Sobrecarga de trabalho em cuidadores de idosos fragilizados que vivem no domicílio. Acta Paul Enferm. 2012;25(5):768-74.

5. Gratão ACM, Talmelli LFS, Figueiredo LC, Rosset I, Freitas (P, Rodrigues RAP. Dependência funcional de idosos e a sobrecarga do cuidador. Rev Esc Enferm USP. 2013;47(1):137-44.

6. Schreiner AS, Morimoto T, Arai Y, Zarit S. Assessing family caregiver's mental health using a statistically derived cut-off score for the Zarit Burden Interview. Aging Ment Health. 2006;10(2):107-11.

7. Uesugui HM, Fagundes DS, Pinho DLM. Perfil e grau de dependência de idosose sobrecarga de seus cuidadores. Acta Paul Enferm. 2011;24(5):689-94.

8. Instituto Brasileiro de Geografia e Estatística. Indicadores sociais municipais: uma análise dos resultados do universo do censo demográfico 2010. Rio de Janeiro: Instituto Brasileiro de Geografía e Estatística; 2011.

9. Valer DB. Adaptação do instrumento Caregiver Burden Inventory para uso com cuidadores de pessoas idosas no Brasil [dissertação]. Porto Alegre (RS): Escola de Enfermagem, Universidade Federal do Rio Grande do Sul; 2012.

10. Ramos LR, Rosa TEC, Oliveira ZM, Medina MCG, Santos FRG. Perfil do idoso em área metropolitana na região sudeste do Brasil: resultados de inquérito domiciliar. Rev Saúde Pública. 1993;27(2):87-94.

11. Scazufca M. Brazilian version of the Burden Interview scale for the assessment of burden of care in carers of people with mental illnesses. Rev Bras Psiquiatr. 2002;24(1):12-7.

12. Vieira S. Introdução á bioestatística. 4. ed. Rio de Janeiro: Elsevier; 2011.

13. Vieira L, Nobre JRS, Bastos CCBC, Tavares KO. Cuidar de um familiar idoso dependente no domicílio: reflexões para os profissionais da saúde. Rev Bras Geriatr Gerontol. 2012;15(2):255-63.

14. Pereira RA, Santos EB, Fhon JRS, Marques S, Rodrigues RAP. Sobrecarga dos cuidadores de idosos com acidente vascular cerebral. Rev Esc Enferm USP. 2013; 47(1):185-92.

15. Loureiro LSN. Sobrecarga em cuidadores familiares de idosos dependentes com vivência comunitária [dissertação]. João Pessoa (PB): Centro de Ciências da Saúde, Universidade Federal da Parába; 2011.

16. Benjamin J, Robbert H, Ruben DMK, Isabelle NF. The effects of an integrated care intervention for the frail elderly on informal caregivers: a quasi-experimental study. BMC Geriatrics. 2014;14:58. 
17. Yurtserver S, Özge A, Kara A, Yandim A, Kalav S, Yesil P. The relationship between care burden and social support in Turkish alzheimer patients family caregivers: cross-sectional study. J Nurs Educn Pract. 2013;3(9):1-12.

18. Morais HCC, Soares AMG, Oliveira ARS, Carvalho CML, Silva MJ, Araujo TL. Sobrecarga e modificações de vida na perspectiva dos cuidadores de pacientes com acidente vascular cerebral. Rev Latino-Am Enfermagem. 2012;20(5):944-53.

19. Aires M. Adaptação da etapa qualitativa do instrumento Filial Responsability [dissertação]. Porto Alegre (RS): Escola de Enfermagem, Universidade Federal do Rio Grande do Sul; 2010.

\section{Author's address:}

Ana Cláudia Fuhrmann

Rua Lobo da Costa, 389/23, Azenha

90050-110, Porto Alegre, RS

E-mail: ana_fuhrmann@hotmail.com
Received: 05.08.2014

Approved: 05.12.2014 